\title{
TITLE:
}

\section{CXCL16 is a novel angiogenic factor for human umbilical vein endothelial cells(Abstract_要旨)}

\author{
$\operatorname{AUTHOR}(\mathrm{S})$ : \\ Zhuge, Xin
}

\section{CITATION:}

Zhuge, Xin. CXCL16 is a novel angiogenic factor for human umbilical vein endothelial cells. 京都大学, 2005, 博士(医学)

ISSUE DATE:

2005-07-25

URL:

http://hdl.handle.net/2433/144481

RIGHT: 


\begin{tabular}{|c|c|}
\hline 名 & $\begin{array}{lll}\text { 諸 架 } & \text { 葛 } \\
\text { 諸 }\end{array}$ \\
\hline 学位 (専攻分野) & 博 士（医 学） \\
\hline 学位記 番号 & 医 博 第 2902 号 \\
\hline 学位授与の日付 & 平成 17 年 7 月 25 日 \\
\hline 学位授与の要件 & 学 位規則 第 4 条第 1 項 該 当 \\
\hline 研究科・専攻 & 医 学研 究 科 内科系 専 攻 \\
\hline 学位論文題目 & $\begin{array}{l}\text { CXCL16 is a novel angiogenic factor for human umbilical vein } \\
\text { endothelial cells } \\
\text { (ケモカイン CXCL16は, ヒト臍帯静脈内皮細胞に対する新規血管新生因子. } \\
\text { である) }\end{array}$ \\
\hline
\end{tabular}

\section{論 文内容 の 要旨}

近年, 腫瘍增殖 ・心血管疾患・慢性炎症・創傷治癒などの過程における血管新生と白血球浸潤の関係について, 強い関心 が寄せられてきた。血管新生と炎症は，血管内皮細胞と白血球がケモカインなどの共通の刺激に反応して起きる共働反応で ある。CXCL16 は，嫣状動脈硬化形成過程で細胞内コレステロール蓄積に関わる独特なケモカインであるが，これまでに この CXCL16 が感染性心内膜炎・リウマチ性および動脈硬化性弁膜症の患者の心臓弁抢よびその新生毛細血管内皮に強く 発現していることが報告されている。本研究で申請者は, CXCL16 が実際に新規血管新生因子として機能して, 直接血管 新生過程に関与しているかどうかを検証した。

まず，ヒト臍帯静脈内皮細胞（HUVEC）を用いた in vitro 実験により，血管新生因子としての CXCL16の機能を評価 した。WST-1による細胞増殖能検定では，CXCL16 存在下に48時間培養すると，HUVEC は量依存的に増殖し，1nMの 濃度で細胞数は対照群より35\%增えることが示された。また，ボイデンチャンバー法による走化性（ケモタキシス）試験で は，CXCL16 は量依存的に HUVECの走化能を増加させ， $1 \mathrm{nM} の$ 濃度で 4 時間刺激すると対照群よりケモタキシスは $40 \%$ 増えた。さらに Matrigel アッセイでHUVEC の管腔形成能を調べると，1nMの CXCL16 の投与により，管腔長の総和は 対照群より1.5倍増加した。

次に，これまでの研究から，さまざまな血管新生因子により惹起される内皮細胞の增殖，遊走，形態形成には ERK の活 性化が深く関わっていることが示されているので，CXCL16を介する情報伝達における ERKの活性化について研究を行っ た。HUVECを CXCL16で刺激すると，時間（10分後に最大）および量（1nMで最大）依存的にERK が活性化された。 CXCL16 刺激の30分前に MEK を阻害する PD98059 化合物で前処置しておくと,この ERK 活性化は完全に阻止された。

最後に，HUVECにおける CXCL16 の血管新生作用に, ERKの活性化が必要かどうかを検証した。PD98059 で前処置 しておくと，CXCL16による細胞増殖と管腔形成は阻止されたが，ケモタキシスはその影響を受けなかった。このことか ら，CXCL16により惹起される HUVEC の細胞増殖と管腔形成には ERK が関与しているが，走化能には関わらないこと が明らかになった。

以上の結果から，CXCL16 は新規血管新生因子として血管新生に直接関与して，血管壁の炎症反応にも重要な役割を果 たしていることが示唆された。本研究は虚血性心疾患や末梢血管開塞症など動脈硬化性疾患に対する治療法を開発する上で 有意義な知見と考えられる。

\section{論 文 審 查の 結 果 の 要 旨}

ケモカイン CXCL16 は，動脈硬化病変や炎症性心弁膜症の内皮に発現し，病態との関連が注目されている。本研究では CXCL16 が血管新生因子として機能するかどうかを検証した。

ヒト臍帯静脈内皮細胞（HUVEC）に拉けるCXCL16 受容体発現を確認した後，この細胞に対する CXCL16の血管新生 
機能を in vitro で解析した。WST-1アッセイで HUVEC は CXCL16 存在下 48 時間培養で量依存的に増殖し, $1 \mathrm{nM}$ の濃度 で細胞数は対照より35\%増加した。また，ボイデンチャンバー法で CXCL16 は用量依存的に HUVEC の走化能を刺激し， $1 \mathrm{nM}$ の濃度で対照よりケモタキシスは40\%増えた。一方 Matrigel アッセイで 1nMの CXCL16 投与は HUVEC 管腔長総和 を対照より1.5倍増加させた。更に CXCL16 は時間および用量依存的にHUVEC の ERK を活性化し，この活性化は MEK 阻害剂 PD98059 の30分間前処置で完全に阻止された。PD98059 前処置は CXCL16 の HUVEC 増殖ならびに管腔形成作用 を阻止したがケモタキシスは影響を受けなかった。以上より，HUVECにおける CXCL16の血管新生作用において，ケモ タキシスは細胞増殖や管腔形成と異なる機構を介すると考兄られた。

以上の研究は CXCL16 が血管新生因子であることを証明し, 動脈硬化性疾患の病態解明に寄与するところが多い。 したがって, 本論文は博士 (医学) の学位論文として価值あるものと認める。

な拉，本学位授与申請者は，平成17年 6 月 27 日実施の論文内容とそれに関連した試問を受け，合格と認められたものであ る。 